\title{
PENGEMBANGAN PROGRAM PEMBELAJARAN PRAKTIKUM FISIKA DASAR BERORIENTASI HEURISTIK TERBIMBING UNTUK MENINGKATKAN KECAKAPAN AKADEMIK MAHASISWA
}

\author{
Wirawan Fadly ${ }^{1)}$ \\ Soegimin W.W ${ }^{2)}$ \\ Sri Poedjiastoeti ${ }^{2)}$ \\ 1) Mahasiswa Pascasarjana Prodi Pendidikan Sains Universitas Negeri Surabaya \\ 2) Dosen Pascasarjana Prodi Pendidikan Sains Universitas Negeri Surabaya \\ e-mail: frogx_fa@yahoo.co.id
}

\begin{abstract}
Abstrack: The main goal of this research is to developed learning program of physics practicum oriented to guided-heuristic for improving students academic skills. The research method used is the R\&D that was conducted in physics laboratory of FMIPA Unesa with research design one-shot case study in trial I and one group pretest-posttest in trial II. Data analysis techniques through quantitative descriptive, qualitative descriptive and inferensial statistics. The results has shown that the learning program of physics practicum oriented to guided-heuristic effectively improved students academic skills.
\end{abstract}

Key words:learning program, physics practicum, guided heuristics, academic skills

\begin{abstract}
Abstrak: Penelitian ini bertujuan mengembangkan program pembelajaran praktikum Fisika Dasar berorientasi heuristik terbimbing untuk meningkatkan kecakapan akademik mahasiswa yang ditinjau dari karakteristik program pembelajaran, kecakapan akademik mahasiswa, peningkatan kecakapan akademik setelah penerapan, respon mahasiswa terhadap penerapan program pembelajaran yang dikembangkan. Metode penelitian yang digunakan adalah $R \& D$ (research and development) dengan desain penelitian one-shot case study pada uji coba I dan one group pretest-posttest design pada uji coba II. Teknik analisis data melalui analisis deskriptif kuantitatif, deskriptif kualitatif dan statistik induktif. Hasil penelitian menunjukkan bahwa program pembelajaran praktikum Fisika Dasar berorientasi heuristik terbimbing yang dikembangkan efektif meningkatkan kecakapan akademik mahasiswa.
\end{abstract}

Kata kunci: ProgramPembelajara, praktikum fisika, heuristik terbimbing, kecakapan akademik.

\section{PENDAHULUAN}

Kualitas sumber daya manusia yang dihasilkan satuan pendidikan tidak terlepas dari proses pembelajaran yang dilakukan. Menurut standar proses pendidikan, proses pembelajaran pada satuan pendidikan perlu diselenggarakan secara interaktif, inspiratif, menyenangkan, menantang, memotivasi peserta didik untuk berpartisipasi aktif, serta memberikan ruang yang cukup bagi prakarsa, kreativitas, dan kemandirian sesuai dengan bakat, minat, dan perkembangan fisik serta psikologis peserta didik. Setiap cabang ilmu pengetahuan termasuk sains Fisika dapat diajarkan sesuai dengan standar proses pendidikan.

Fisika merupakan salah satu bagian dari sains yang dibangun dari penalaran deduktif dan penemuan induktif. Dalam pembelajaran Fisika perlu memperhatikan unsur sains sebagai ilmu pengetahuan teoritis yang diperoleh melalui cara yang khusus, yaitu melakukan pengamatan, percobaan, penyusunan teori, dan penyimpulan yang saling kait-mengkait antara cara satu dengan cara yang lain. Oleh karena itu, proses pembelajaran Fisika seharusnya tidak hanya menyangkut olah pikir, akan tetapi juga memperhatikan olah tangan melalui kerja praktek.
Kegiatan praktikum merupakan suatu cara penyajian pelajaran dimana peserta didik melakukan percobaan melalui kerja praktek dengan melaksanakan maupun membuktikan sendiri sesuatu yang dipelajari. Kegiatan praktikum akan memberikan kesempatan pada peserta didik untuk mengalami dan melakukan sendiri, mengikuti suatu proses, mengamati suatu objek, menganalisis, dan menarik kesimpulan secara mandiri. Hal ini sesuai dengan kurikulum tingkat satuan pendidikan (KTSP), dimana pembelajaran Fisika hendaknya dilaksanakan secara penemuan dan penyelidikan ilmiah untuk menumbuhkan salah satu aspek penting kecakapan hidup yaitu kecakapan akademik. Kecakapan akademik ini terkait dengan bidang pekerjaan yang lebih memerlukan pemikiran atau kerja intelektual.

Pendekatan heuristik dapat memfasilitasi proses pembelajaran melalui penemuaan dan penyelidikan ilmiah. Menurut Donovan et.al, pada setiap aspek pendekatan heuristik terbimbing meyajikan perbedaan tantangan, dimana pada pelaksanaannya menekankan pada aktivitas berpikir disertai dengan aktivitas kinerja. Aktivitas berpikir (mind-on) adalah kemampuan mempertanyakan dan mencari jawaban sesuai dengan 
tingkat pengetahuan peserta didik dalam memperoleh pemahaman, sedangkan aktivitas kinerja (hand-on) adalah kegiatan penyelidikan ilmiah untuk mencari dan menemukan pengetahuan melalui olah tangan atau kerja praktek. Pendekatan ini sangat baik digunakan untuk mendesain pembelajaran dan mengembangkan kecakapan akademik, karena memberikan ruang kepada peserta didik untuk belajar sesuai dengan gaya belajar mereka sendiri.

Dari hasil penelitian pendahuluan ditemukan bahwa kecakapan akademik mahasiswa di FMIPA Unesa masih belum sesuai dengan harapan. Hal ini dapat dilihat dari hasil tes penguasaan pengetahuan dan keterampilan ilmiah setelah mahasiswa mengikuti kegiatan praktikum yang masih kurang, dengan nilai rata-rata masing-masing 63,5 dan 58,8. Survei lapangan yang dilakukan ditemukan bahwa (1) kerangka program hanya sebatas jadwal kegiatan praktikum, (2) perangkat pembelajaran yang dibuat hanya buku panduan dan Lembar Kegiatan Pratikum, (3) lembar penilaian tidak disertai dengan rubrik penilaian yang jelas, (4) mahasiswa kurang dilibatkan dalam membangun konsep, (5) mahasiswa hanya menjalankan petunjuk rinci pada LKP bukan melatih kemandirian, (6) kurangnya interaksi antara koasisten dengan mahasiswa untuk melakukan pembimbingan, (7) belum ada penilaian kinerja, penilaian hanya dilakukan melalui tes tulis.

Dari hasil tersebut mengindikasikan bahwa perlu disusun program pembelajaran yang fokus terhadap peningkatan kecakapan akademik. Menurut Herry program pembelajaran memiliki peran sangat strategis dalam pencapaian tujuan pendidikan yaitu sebagai sarana mengembangkan potensi untuk memperoleh pengetahuan baru. Program pembelajaran tersebut perlu diimplementasikan dalam bentuk kegiatan praktikum dapat membangkitkan motivasi belajar dan mengembangkan keterampilan dasar melalui kerja praktek. Pendekatan yang sesuai untuk meningkatkan kecakapan akademik yaitu pendekatan heuristik terbimbing. Hal ini sesuai dengan pendapat pendapat para ahli yang menyatakan bahwa: heuristik merupakan proses metakognisi yang baik digunakan untuk meningkatkan keterampilan ilmiah dan pemecahan masalah, melalui pembelajaran terbimbing peserta didik dibebaskan untuk menerka, mencoba, menyelidiki dan memecahkan masalah dan baik digunakan untuk mengajarkan konsep abstrak, meningkatkan kinerja dan pemahaman konsep.

Berdasarkan latar belakang tersebut maka dirumuskan masalah penelitian sebagai berikut:

1. Bagaimana karakteristik program pembelajaran yang dikembangkan?
2. Bagaimana peningkatan kecakapan akademik mahasiswa dengan menerapkan program pembelajaran yang dikembangkan?

3. Bagaimana motivasi belajar mahasiswa terhadap program pembelajaran yang dikembangkan?

\section{METODE PENELITIAN}

Metode penelitian yang digunakan adalah R\&D (research and development). Secara garis besar metode R\&D terdiri dari tiga langkah penelitian [1] yaitu: (1) studi pendahuluan meliputi studi pustaka dan survei lapangan untuk mengamati produk atau kegiatan yang ada; (2) melakukan pengembangan produk meliputi penyusunan draf produk, validasi, dan uji coba produk; dan (3) pengujian produk. Berikut rancangan R \& D yang digunakan dalam penelitian ini:

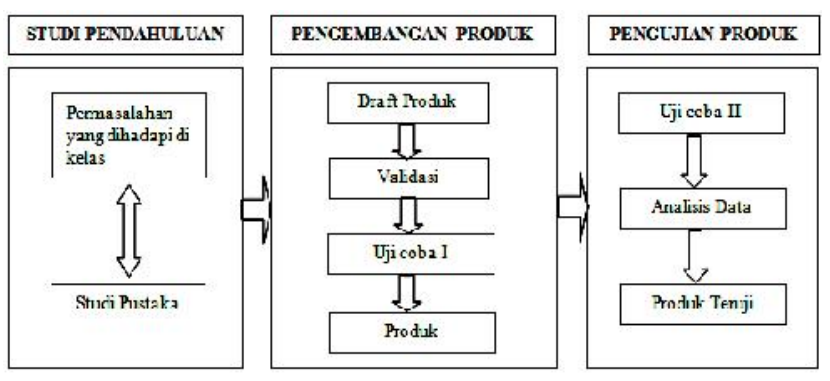

Gambar 1. Langkah-langkah metode R\&D

Pada tahap studi pendahuluan bertujuan untuk mendeskripsikan dan menganalisis permasalahan yang ada di lapangan yang berhubungan dengan program pembelajaran praktikum Fisika Dasar II. Fokus kegiatan yang dilakukan pada tahap ini yaitu dengan mengumpulkan informasi sebanyak-banyaknya melalui studi pustaka, berkonsultasi dan melakukan peninjauan langsung. Studi pustaka dilakukan dengan membaca literatur baik teori maupun penelitian terdahulu yang relevan dengan masalah dan tujuan penelitian. Konsultasi dilakukan untuk memperoleh informasi tentang keadaan di lapangan maupun arahan dari para ahli atau manusia sumber. Peninjauan langsung ini dimaksudkan agar mengetahui kondisi riil yang akan diteliti terutama kelebihan dan kekurangan yang ada pada program pembelajaran yang selama ini digunakan, hal ini dilakukan untuk mendapatkan gambaran dan masukan terhadap program pembelajaran yang akan dikembangkan. Dari ketiga kegiatan tersebut kemudian hasilnya dianalisis dan dideskripsikan sehingga dapat dijadikan acuan dalam pengembangan produk yaitu program pembelajaran praktikum Fisika Dasar II.

Berdasarkan analisis dan temuan pada studi pendahuluan maka produk yang akan dikembangkan berupa program pembelajaran praktikum Fisika Dasar yang diorientasikan pada pendekatan heuristik terbimbing. Pada tahapan pengembangan produk 
dilakukan kegiatan yang meliputi: penyusunan dan pengembangan draft produk, validasi, uji coba I, evaluasi dan perbaikan. Pada kegiatan penyusunan draft dirancang prototipe produk. Dalam penyusunan draft produk ini yang pertama kali yang dilakukan yaitu menetapkan tujuan kegiatan praktikum. Setelah dilakukan penyusunan dan penetapan tujuan kegiatan praktikum kemudian dikembangkan draft produk.

Pengembangan draft produk dilakukan menggunakan model pengembangan Kemp. Draft produk yang dihasilkan yaitu berupa kerangka program pembelajaran praktikum, perangkat pembelajaran, dan lembar penilaian. Kerangka program pembelajaran terdiri dari deskripsi program, GBPP dan silabus. Perangkat pembelajaran terdiri dari: SAP, buku panduan, lembar kegiatan praktikum, kisi-kisi dan soal tes. Lembar penilaian terdiri dari: validasi program pembelajaran, penguasaan pengetahuan, keterampilan ilmiah, dan kinerja.

Validasi dilakukan oleh dua orang ahli pendidikan dan satu orang praktisi yang memiliki kompetensi menilai program pembelajaran. Hal ini dilakukan agar mendapatkan masukan sehingga akan meningkatkan validitas produk tersebut. Dari hasil validasi, kemudian dilakukan revisi untuk menyempurnakan produk yang dikembangkan.

Uji coba I dilakukan setelah revisi. Uji coba I difokuskan untuk menguji substansi isi dan fleksibilitas produk. Uji coba I hanya dilakukan pada populasi kecil yaitu pada mahasiswa jurusan Fisika FMIPA Unesa yang mengikuti perkuliahan Fisika Dasar I yang terdiri dari tiga prodi yaitu S1 Pendidikan Fisika reguler, S1 Pendidikan Fisika non reguler dan S1 Fisika. Teknik pemilihan sampel dilakukan melalui sampel proporsi yaitu dengan mengambil perwakilan dari masing-masing prodi. Desain penelitian pada uji coba I menggunakan one-shot case study.

Pada tahap pengujian bertujuan untuk mengetahui substansi isi dan fleksibilitas produk, dan peningkatan kecakapan akademik mahasiswa setelah menggunakan produk yang telah dikembangkan. Kegiatan pada tahap ini meliputi uji coba II dan perbaikan akhir. Kegiatan uji coba II dilakukan pada populasi yang lebih banyak yaitu pada beberapa jurusan di FMIPA Unesa yang mengikuti perkuliahan Fisika Dasar II. Jurusan tersebut terdiri dari jurusan Kimia, Biologi, dan Fisika. Teknik pemilihan sampel dilakukan melalui sampel proporsi yaitu dengan mengambil perwakilan dari masing-masing jurusan. Berbeda dengan uji coba I, uji coba II menggunakan desain one group pretest-posttest.

Pengumpulan data menggunakan berbagai teknik yang relevan dengan data yang diperlukan. Pada tahap studi pendahuluan menggunakan studi dokumen, kuesioner dan observasi. Pada tahap pengembangan menggunakan teknik penilaian ahli, kuesioner, tes. Teknik observasi, tes, penilaian produk dan kuesioner dilakukan pada tahap pengujian produk.

Teknik analisis data melalui analisis deskriptif kuantitatif, deskriptif kualitatif dan statistik inferensial menggunakan uji-t dan uji jenjang-bertanda Wilcoxon. Uji coba I dilakukan pada 9 mahasiswa dari program studi di jurusan Fisika, dan uji coba II dilakukan pada 29 mahasiswa dari jurusan Fisika, Biologi dan Kimia.

\section{HASIL DAN PEMBAHASAN}

\section{Karakteristik Program}

a. Perencanaan

Pada perencanaan dihasilkan produk program pembelajaran yaitu kerangka program pembelajaran (pendahuluan, garis besar program pengajaran/GBPP dan silabus), perangkat pembelajaran (satuan acara perkuliahan/SAP, buku ajar dan lembar kegiatan praktikum), dan lembar penilaian (kognitif, psikomotor dan kinerja). Kerangka program yang dikembangkan mempunyai karakteristik sebagai berikut: (a) menitikberatkan pada penguasaan pengetahuan dan kecakapan akademik mahasiswa; (b) berisi informasi umum kegiatan praktikum selama satu semester; (c) disesuaiakan dengan pendekatan penemuan, penyelidikan dan pembimbingan atau heuristik terbimbing; (d) tujuan pembelajaran dijabarkan secara hierarki dan relevan dari segi yang paling tinggi tingkatannya kepada yang paling operasional; (e) pendahuluan, GBPP dan silabus saling berkaitan; (f) digunakan sebagai acuan untuk mengembangkan perangkat pembelajaran.

Perangkat pembelajaran yang dikembangkan mempunyai karakteristik sebagai berikut: (a) mengembangkan penguasaan pengetahuan dan kecakapan akademik mahasiswa; (b) berisi rencana, panduan, informasi, unjuk kerja dan alat ukur dalam pelaksanaan pembelajaran; (c) diorientasikan pada pendekatan penemuan, penyelidikan dan pembimbingan atau heuristik terbimbing; (d) buku ajar,lembar kerja pratikum/ LKP, lembar evaluasi dilaksanakan berdasarkan panduan SAP.

Lembar penilaian yang dikembangkan mempunyai karakteristik sebagai berikut: (a) mencakup penilaian kognitif, psikomotor dan kinerja; (b) memudahkan dalam melakukan penilaian karena disediakan rubrik, kunci jawaban dan pedoman pensekoran; (c) bentuk dan teknik penilaiannya jelas.

Hasil penilaian ahli dan praktisi terhadap produk program pembelajaran memiliki kategori baik untuk seluruh penilaian komponen (kerangka program, perangkat pembelajaran dan lembar penilaian), penyajian, dan bahasa. Oleh karena itu, produk program pembelajaran yang dikembangkan dapat digunakan pada 
kegiatan praktikum Fisika Dasar. Saran-saran yang diberikan oleh para ahli sebagai perbaikan diantaranya pada kerangka program perlu diberikan rumus dalam penilaian beserta kriterianya, pada buku panduan perlu diberikan tugas pendahuluan sebelum pralaboratorium dan perlu diberi potongan pertanyaan (chunking) pada setiap komponen yang dilatihkan sebagai pembimbingan.

\section{b. Pelaksanaan}

Pada pelaksanaan pembelajaran akan dibahas keterlaksanaan pembelajaran, aktivitas dosen dan mahasiswa, dan kinerja mahasiswa. Pengamatan keterlaksanaan pembelajaran dengan menggunakan program pembelajaran praktikum fisika dasar berorientasi heuristik terbimbing dilakukan oleh dua orang pengamat pada pada setiap tahap kegiatan. Pengamatan dilakukan menggunakan lembar pengamatan keterlaksanaan pembelajaran. Secara ringkas hasil pengamatan keterlaksanaan pembelajaran dapat dilihat pada Tabel 1 berikut ini.
Dari Tabel 1 tersebut diketahui bahwa persentase keterlaksanaan pembelajaran tinggi dengan kegiatan pembelajaran yang diorientasikan pada pendekatan heuristik terbimbing. Persentase keterlaksanaan pembelajaran yang tinggi ini mengindikasikan bahwa (1) Pembelajaran yang direncanakan baik, merupakan salah satu faktor keberhasilan proses pembelajaran. (2) Perangkat pembelajaran dikembangkan dilengkapi dengan kegiatan pembimbingan, pada SAP kegiatan pembimbingan berupa pertanyaan pemandu dan pada buku ajar dan LKP dilengkapi dengan pembimbingan dalam bentuk kalimat scaffolding. (3) Penguasaan dosen terhadap seluruh perangkat yang dikembangkan dan komitmen yang tinggi dalam melaksanakan pembelajaran sesuai dengan perangkat tersebut Aktivitas mahasiswa diamati selama kegiatan pembelajaran yang meliputi

Tabel 1. Keterlaksanaan Pembelajaran

\begin{tabular}{|c|l|c|}
\hline No & \multicolumn{1}{|c|}{ Tahapan Kegiatan } & $\begin{array}{c}\text { Rata-rata } \\
\text { keterlaksanaan } \\
(\%)\end{array}$ \\
\hline 1 & Pralaboratorium & 91 \\
\hline 2 & Kegiatan Laboratorium & 95 \\
\hline 3 & Postlaboratorium & 90 \\
\hline \multicolumn{2}{r|}{ Rata-rata total } & 92 \\
\hline
\end{tabular}

Tabel 2. Aktivitas Mahasiswa Pada Pra-Laboratorium

\begin{tabular}{|c|c|c|c|c|c|c|c|c|}
\hline \multirow[b]{2}{*}{ No } & \multirow[b]{2}{*}{ Aktivitas Mahasiswa } & \multicolumn{4}{|c|}{ Pengamat } & \multirow[b]{2}{*}{$\%$} & \multicolumn{2}{|c|}{ Reliabilitas } \\
\hline & & P1 & P2 & $\mathrm{SP}$ & $\overline{\mathrm{P}}$ & & $\mathbf{R}$ & $\overline{\mathrm{R}}$ \\
\hline 1 & $\begin{array}{l}\text { Membaza (mencari infomesi dan } \\
\text { sebagainya) }\end{array}$ & 13 & 14 & 27 & 13.5 & $10 \%$ & $96 \%$ & $94 \%$ \\
\hline 2 & Mendiskusikan tugas & 18 & 16 & 34 & 17 & $13 \%$ & $94 \%$ & \\
\hline 3 & Mencatat & 11 & 13 & 24 & 12 & $9 \%$ & $92 \%$ & \\
\hline 4 & Mendengarkan penjelasan dosen & 21 & 18 & 39 & 19.5 & $15 \%$ & $92 \%$ & \\
\hline 5 & Merencanakan Praktikum & 32 & 35 & 67 & 33.5 & $25 \%$ & $96 \%$ & \\
\hline 6 & Bertanya pada dosen & 10 & 12 & 22 & 11 & $8 \%$ & $91 \%$ & \\
\hline 7 & $\begin{array}{l}\text { Menyampaikan } \\
\text { pendapat mengkcmunkasikan } \\
\text { informasi kepada doscn }\end{array}$ & 18 & 18 & 36 & 18 & $13 \%$ & $100 \%$ & \\
\hline 8 & Perilaku tidak relevan & 9 & 10 & 19 & 9.5 & $7 \%$ & $95 \%$ & \\
\hline & Jumlail & 156 & 132 & 136 & 268 & 134 & & \\
\hline
\end{tabular}

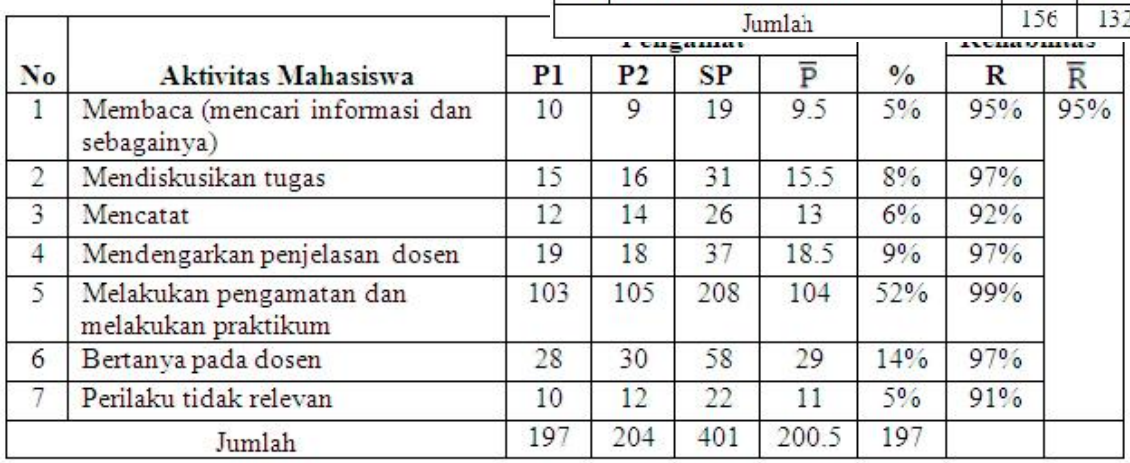

Tabel 3. Aktivitas Mahasiswa Pada Kegiatan Laboratorium

\begin{tabular}{|c|c|c|c|c|c|c|c|c|}
\hline \multirow[b]{2}{*}{ No } & \multirow[b]{2}{*}{ Aktivitas Mahasiswa } & \multicolumn{4}{|c|}{ Pengamat } & \multirow[b]{2}{*}{$\%$} & \multicolumn{2}{|c|}{ Reliabilitas } \\
\hline & & Pl & P2 & SP & $\overline{\mathrm{P}}$ & & $\mathbf{R}$ & $\overline{\mathrm{R}}$ \\
\hline 1 & Mendiskusikan tugas & 15 & 14 & 29 & 14.5 & $12 \%$ & $97 \%$ & \multirow[t]{6}{*}{$96 \%$} \\
\hline 2 & Mencatat & 15 & 16 & 31 & 15.5 & $13 \%$ & $97 \%$ & \\
\hline 3 & Mendengarkan penjelasan dosen & 25 & 23 & 48 & 24 & $20 \%$ & $96 \%$ & \\
\hline 4 & Bertanya pada dosen & 30 & 29 & 59 & 29.5 & $25 \%$ & $98 \%$ & \\
\hline 5 & $\begin{array}{l}\text { Menyampaikan } \\
\text { pendapat/mengkomunikasikan } \\
\text { informasi kepada kelas dan dosen }\end{array}$ & 24 & 22 & 46 & 23 & $19 \%$ & $96 \%$ & \\
\hline 6 & Perilaku tidak relevan & 12 & 11 & 23 & 11.5 & $10 \%$ & $96 \%$ & \\
\hline \multicolumn{2}{|r|}{ Jumlah } & 121 & 115 & 236 & 118 & & & \\
\hline
\end{tabular}

Tabel 4. Aktivitas Mahasiswa Pada Post-Laboratorium 
Dari pemaparan Tabel, 2, 3, dan 4 diketahui bahwa aktivitas yang paling dominan pada setiap tahapanya adalah aktivitas yang berpusat pada mahasiswa, hal ini dapat dilihat pada tahap kegiatan laboratorium dan post laboratorium mahasiswa diberikan kebebasan untuk melakukan kegiatan heuristik untuk menemukan konsep/prinsip oleh diri mereka sendiri. Menurut Rogers mengatakan pengajaran yang berpusat pada mahasiswa memberi kebebasan agar mahasiswa memilih kegiatan yang dirasanya perl $\mathrm{u}$ atas tanggung jawab sendiri [14]. Pada pembelajaran yang berpusat pada mahasiswa ini dosen bertindak sebagai fasilitator untuk melakukan pembimbingan agar pembentukan konsep menjadi lebih bermakna. Hal ini sesuai dengan karakteristik heuristik terbimbing diantaranya guru tidak membuat jarak yang

Penilaian kinerja mahasiwa menunjukkan bahwa kinerja mahasiswa baik pada setiap tahapannya. Kinerja yang dilakukan pada tiap tahapan meliputi perencanaan praktikum, pengumpulan data, pembuatan laporan dan seminar hasil praktikum.

\section{Peningkatan Kecakapan Akademik Mahasiswa}

Kecakapan akademik memiliki dua komponen utama yaitu penguasaan pengetahuan dan keterampilan ilmiah. Oleh karena itu, dalam melihat peningkatan kecakapan akademik mahasiswa dapat dilihat dari tidak terlalu tajam dengan mahasiswa, tetapi menempatkan diri berdampingan dengan mahasiswa dengan posisi siap memberi bantuan belajar.

Kinerja mahasiswa diamati untuk melihat sejauh mana pengerjaan tugas yang dilakukan pada setiap tahap pembelajaran. Hasil penilaian kinerja disajikan pada tabel berikut:

Tabel 5. Kinerja Mahasiswa Selama Pembelajaran

\begin{tabular}{|c|c|c|}
\hline Kegiatan Praktikum & Skor & Kategori \\
\hline Pralaboatorium & 3.0 & Baik \\
\hline Kegiatan Laboratorium & 2.9 & Baik \\
\hline Postlaboratorium & 3.2 & Baik \\
\hline Rata-rata Kinerja & 3.0 & Baik \\
\hline
\end{tabular}

peningkatan komponennya yaitu berdasarkan peningkatan penguasaan pengetahuan dan keterampilan ilmiah mahasiswa.

Data hasil penguasaan pengetahuan kognitif digunakan untuk melihat ketuntasan indikator dan kriteria penguasaan pengetahuan kognitif secara individu dan klasikal. Ketuntasan indikator menggunakan program pembelajaran praktikum berorientasi heuristik terbimbing dapat dilihat pada Tabel 6 berikut ini

Tabel 6a. Penguasaan Pengetahuan Kognitif Mahasiswa

\begin{tabular}{|c|c|c|c|c|c|}
\hline \multirow{2}{*}{ No. } & \multirow{2}{*}{ Indikator } & \multicolumn{2}{|c|}{ O1 } & \multicolumn{2}{|c|}{$\mathrm{O} 2$} \\
\hline & & Nilai & Kriteria & Nilai & Kriteria \\
\hline 1. & $\begin{array}{l}\text { Mentebutkan bagian-bagian } \\
\text { rangkaian RLC }\end{array}$ & 43,1 & TT & 79,7 & $\mathrm{~T}$ \\
\hline 2. & $\begin{array}{l}\text { Menggambar diagram fasor pada } \\
\text { rangkaian RLC }\end{array}$ & 32,4 & TT & 66,9 & $\mathrm{~T}$ \\
\hline 3. & $\begin{array}{l}\text { Menentukan besar impedansi, } \\
\text { kuat arus dan beda fase pada } \\
\text { rangkaian seri RLC }\end{array}$ & 35,5 & TT & 73,4 & $\mathrm{~T}$ \\
\hline 4. & $\begin{array}{l}\text { Menganalisis pengaruh besar } \\
\text { tegangan terhadap kuat arus }\end{array}$ & 39,1 & TT & 76,6 & $\mathrm{~T}$ \\
\hline 5. & $\begin{array}{l}\text { Menentukan pasangan rumusan } \\
\text { masalah-prediksi yang sesuai } \\
\text { dengan kasus }\end{array}$ & 46,2 & TT & 78,3 & $\mathrm{~T}$ \\
\hline 6. & $\begin{array}{l}\text { Merancang praktikum untuk } \\
\text { mengukur besarnya induktansi } \\
\text { induktor pada rangkaian RL }\end{array}$ & 40,0 & TT & 73,4 & $\mathrm{~T}$ \\
\hline & Rata-rata & 39,4 & TT & 74,7 & $\mathrm{~T}$ \\
\hline
\end{tabular}

Tabel 6b. Penguasaan Pengetahuan Psikomotorik Mahasiswa

\begin{tabular}{|c|l|c|c|c|c|}
\hline \multirow{2}{*}{ No } & \multirow{2}{*}{ Indikator } & \multicolumn{2}{|c|}{ Pretest } & \multicolumn{2}{c|}{ Posttest } \\
\cline { 3 - 6 } & & Nilai & Kriteria & Nilai & Kriteria \\
\hline 1 & Merumuskan masalah & 48.9 & $\mathrm{TT}$ & 75.9 & $\mathrm{~T}$ \\
\hline 2 & Mengidentifikasi variabel & 47.3 & $\mathrm{TT}$ & 76.8 & $\mathrm{~T}$ \\
\hline 3 & Merumuskan DOV & 48.3 & $\mathrm{TT}$ & 72.4 & $\mathrm{~T}$ \\
\hline 4 & $\begin{array}{l}\text { Merancang penelitian dan } \\
\text { melaksanakan penelitian }\end{array}$ & 44.8 & $\mathrm{TT}$ & 72.4 & $\mathrm{~T}$ \\
\hline 5 & Berkomunikasi ilmiah & 48.3 & $\mathrm{TT}$ & 74.8 & $\mathrm{~T}$ \\
\hline 6 & Membuat kesimpulan & 47.4 & $\mathrm{TT}$ & 74.6 & $\mathrm{~T}$ \\
\hline & Rata-rata & 47.5 & $\mathrm{TT}$ & 74.5 & $\mathrm{~T}$ \\
\hline
\end{tabular}


Tabel 7. Penguasaan Keterampilan Ilmiah Mahasiswa

\begin{tabular}{|c|c|c|c|c|c|}
\hline \multirow{2}{*}{ No } & \multirow{2}{*}{ Indikator } & \multicolumn{2}{|c|}{ Pretest } & \multicolumn{2}{|c|}{ Posttest } \\
\hline & & Nilai & Kriteria & Nilai & Kriteria \\
\hline 1 & $\begin{array}{l}\text { Menggunakan } \\
\text { Multimeter }\end{array}$ & 39.1 & TT & 72.7 & $\mathrm{~T}$ \\
\hline 2 & $\begin{array}{l}\text { Membaca Skala } \\
\text { Multimeter }\end{array}$ & 40.1 & TT & 73.5 & $\mathrm{~T}$ \\
\hline 3 & $\begin{array}{l}\text { Merangkai alat dan } \\
\text { bahan }\end{array}$ & 39.4 & $\mathrm{TT}$ & 70.4 & $\mathrm{~T}$ \\
\hline & Rata-rata & 39.5 & TT & 72.2 & $\mathrm{~T}$ \\
\hline
\end{tabular}

Dari pemaparan Tabel 6-7 dapat diketahui bahwa ketuntasan indikator penguasaan pengetahuan kognitif, penguasaan pengetahuan psikomotor dan keterampilan ilmiah masing-masing sebesar $100 \%$. Hal ini menunjukkan bahwa indikator telah tercapai. Nilai dan kriteria klasikal penguasaan pengetahuan dan ketrampilan ilmiah setelah menerapkan program pembelajaran yang dikembangkan masing-masing sebesar 73,6 dengan kriteria B (baik) dan 74,4 dengan kriteria B (baik).

Fleksibilitas program pembelajaran terhadap hasil kecakapan akademik pada penguasaan pengetahuan dan ketrampilan ilmiah dilakukan dengan menggunakan uji-t. Program pembelajaran dapat dikatakan fleksibel apabila tidak terjadi perbedaan hasil yang signifikan pada setiap kelas yang menerapkan program tersebut. Uji-t ini dilakukan pada hasil penguasaan pengetahuan dan ketrampilan ilmiah setelah melaksanakan program pembelajaran pada tiga jurusan berbeda dalam satu fakultas yang dapat dilihat pada tabel berikut.

Tabel 8. Fleksibilitas penguasaan pengetahuan

\begin{tabular}{|c|c|c|c|c|c|c|c|c|}
\hline No & Prodi & Rerata & $S_{d}$ & $S_{d}{ }^{2}$ & $S_{\text {gab }}$ & $\mathrm{dk}$ & $t_{\text {hitung }}$ & $\mathrm{t}_{\text {Tabel }}$ \\
\hline \multirow{2}{*}{1} & Fisika & 72.6 & 4.06 & 16.50 & \multirow{2}{*}{3.16} & \multirow{2}{*}{20} & \multirow{2}{*}{0.91} & \multirow{2}{*}{2.09} \\
\hline & Kimia & 75.0 & 3.47 & 12.07 & & & & \\
\hline \multirow{2}{*}{2} & Fisika & 72.6 & 4.06 & 16.50 & \multirow{2}{*}{3.33} & \multirow{2}{*}{20} & \multirow{2}{*}{0.65} & \multirow{2}{*}{2.09} \\
\hline & Biologi & 74.4 & 5.66 & 32.07 & & & & \\
\hline \multirow{2}{*}{3} & Kimia & 75.0 & 3.47 & 12.07 & \multirow{2}{*}{2.98} & \multirow{2}{*}{12} & \multirow{2}{*}{0.24} & \multirow{2}{*}{2.18} \\
\hline & Biologi & 74.4 & 5.66 & 32.07 & & & & \\
\hline
\end{tabular}

Tabel 9. Fleksibilitas Program Pembelajaran pada Ketrampilan Ilmiah

\begin{tabular}{|c|c|c|c|c|c|c|c|c|}
\hline No & Prodi & Rerata & $S_{d}$ & $\mathrm{~S}_{\mathrm{d}}^{2}$ & $S_{\text {gab }}$ & $\mathrm{dk}$ & $t_{\text {hitung }}$ & $\mathrm{t}_{\text {Tabel }}$ \\
\hline \multirow{2}{*}{1} & Fisika & 74.3 & 3.87 & 14.99 & \multirow{2}{*}{3.11} & \multirow{2}{*}{20} & \multirow{2}{*}{0.44} & \multirow{2}{*}{2.09} \\
\hline & Kimia & 75.5 & 4.30 & 18.45 & & & & \\
\hline \multirow{2}{*}{2} & Fisika & 74.3 & 3.87 & 14.99 & \multirow{2}{*}{3.26} & \multirow{2}{*}{20} & \multirow{2}{*}{0.28} & \multirow{2}{*}{2.09} \\
\hline & Biologi & 73.6 & 6.33 & 40.06 & & & & \\
\hline \multirow{2}{*}{3} & Kimia & 75.5 & 4.30 & 18.45 & \multirow{2}{*}{3.52} & \multirow{2}{*}{12} & \multirow{2}{*}{0.65} & \multirow{2}{*}{2.18} \\
\hline & Biologi & 73.6 & 6.33 & 40.06 & & & & \\
\hline
\end{tabular}

Berdasarkan Tabel 8,9 tersebut dapat dilihat bahwa uji-t yang dilakukan pada ketiga nomor dihasilkan bahwa $t_{\text {hitung }}<t_{\text {tabel }}$, jadi hipotesis masing-masing diterima, sehingga dapat dinyatakan bahwa program pembelajaran praktikum Fisika Dasar berorientasi heuristik terbimbing efektif dan fleksibel $(\alpha=0,05)$ digunakan dalam pencapaian penguasaan pengetahuan dan keterampilan ilmiah mahasiswa.

Untuk mengetahui signifikansi peningkatan penguasaan pengetahuan dan keterampilan ilmiah data yang diperoleh kemudian diuji normalitas dan homogenitasnya. Karena data tidak normal namun homogen maka dilakukan uji jenjang-bertanda Wilcoxon antara hasil penguasaan pengetahuan dan keterampilan ilmiah sebelum dengan setelah pelaksanaan program pembelajaran. Data hasil uji statistik dengan $\alpha=0,05$ dihasilkan bahwa $Z_{\text {hitung }}>Z_{\text {tabel, }}$, sehingga hipotesis ditolak yang artinya bahwa pelaksanaan program pembelajaran berorientasi heuristik terbimbing dapat meningkatkan indikator dan hasil penguasaan pengetahuan dan keterampilan ilmiah mahasiswa. Temuan ini juga sejalan dengan penelitian Knowlton et.al 
yang menerapkan pembelajaran dengan pendekatan heuristik pada siswa berkebutuhan khusus dimana pendekatan heuristik sangat baik digunakan untuk mendesain pembelajaran dan mengembangan keterampilan proses, karena memberikan ruang kepada siswa untuk belajar sesuai dengan gaya belajar mereka. Hasil ini juga didukung oleh pendapat Donovan et.al [4] yang menyatakan bahwa pada setiap aspek pendekatan heuristik meyajikan perbedaan tantangan, dimana pada pelaksanaannya menekankan pada kemampuan berpikir dalam menjelasankan ide (berisi konsep dan teori) disertai dengan aktivitas melalui penyelidikan ilmiah.

\section{Motivasi Belajar Mahasiswa}

Motivasi belajar mahasiswa yang meliputi perhatian, relevansi, kepercayaan diri, dan kepuasan terhadap penerapan program pembelajaran praktikum Fisika Dasar berorientasi heuristik terbimbing yang dikembangkan adalah baik, hal ini dapat dilihat pada grafik dibawah ini

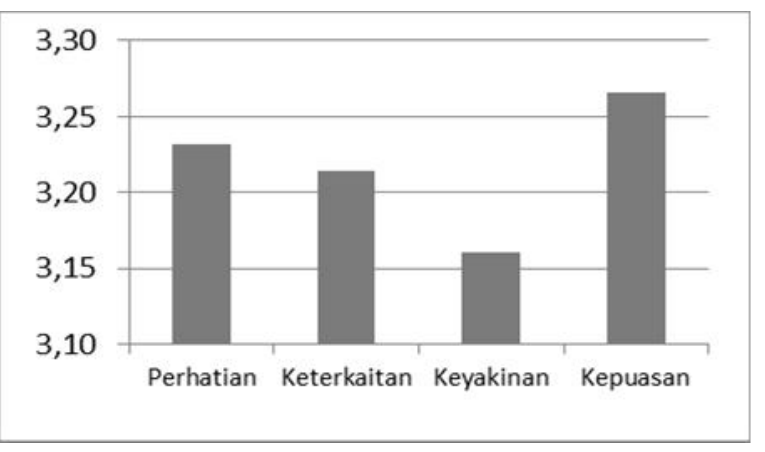

Gambar 2. Motivasi Belajar Mahasiswa

Berdasarkan Gambar 2 menunjukkan bahwa motivasi belajar mahasiswa berkembang baik setelah menerapkan program pembelajaran yang dikembangkan. Pada aspek perhatian menunjukkan bahwa selama pembelajaran mahasiswa memperhatikan pembelajaran dengan baik, hal ini secara tidak langsung akan mengurangi aktivitas yang tidak relevan karena aktivitas mahasiswa lebih terfokus pada pembelajaran. Aspek keterkaitan baik, hal ini menunjukkan bahwa penerapan program yang dikembangkan dapat menumbuhkan keterkaiatan antar kegiatan pembelajaran dengan manfaat yang diperoleh dalam kehidupan sehari-hari, dengan keterkaitan ini mahasiswa akan lebih mudah memahami suatu pengetahuan [16]. Kepercayaan diri baik, respons tersebut menunjukkan bahwa dengan penerapan program yang dikembangkan dapat menumbuhkan rasa percaya diri mahasiswa. Dengan rasa percaya diri mahasiswa akan dapat mencapai tujuan secara efektif melalui kegiatan yang mereka lakukan sendiri. Aspek kepuasan baik dan memiliki skor yang paling tinggi, respons tersebut menunjukkan bahwa dengan penerapan program pembelajaran yang dikembangkan dapat menumbuhkan kepuasan mahasiswa terhadap proses dan hasil belajar. Dengan rasa kepuasan tersebut mahasiswa akan cenderung untuk mengulangi proses dan hasil belajar tersebut.

\section{SIMPULAN}

Berdasarkan hasil dan pembahasan dapat disimpulkan bahwa program pembelajaran praktikum Fisika Dasar berorientasi heuristik terbimbing yang dikembangkan efektif untuk meningkatkan kecakapan akademik mahasiswa. Beberapa kelebihan program pembelajaran yang dikembangkan yaitu: pembelajaran diorientasikan pada kegiatan penemuan, penyelidikan, pembimbingan, berpusat pada mahasiswa, dan mengembangkan motivasi belajar mahasiswa.

\section{DAFTAR PUSTAKA}

Borg and Gall M.D. 2001. Educational Research. Boston: Pearson Education, Inc.

Depdiknas. 2006. Kurikulum Tingkat Satuan Pendidikan untuk SMP dan MTs. Jakarta: Departemen Pendidikan Nasional

-----------. 2009. Model Integrasi Pendidikan Kecakapan Hidup. Jakarta: Puskur Depdiknas

Donovan, S. and Pellegrino, J. W. 2000. How People Learn: Brain, Mind, Experience, and School. Washington DC: The National Academies Press

Frey, N. and Fisher, D. 2010. Identiying Instructional Moves During Guided Learning. The Reading A Teacher. 64(2) pp. 84-95

Gigerenzer, G. 1991. From Tools to Theories: A Heuristic of Discovery in Cognitive Psychology. Psychological Journal Review. 254-267

Herry, A. 2008. Pengembangan Kurikulum dan Pembelajaran. Jakarta: Universitas Terbuka

Howe, A. C. and Linda J. 1993. Engaging Children In Science. New York: Mcmillan Publishing Company

Knowlton, D and Thomeczek, M. 2007. HeuristicGuided Instructional Strategy Development ForPeripheral Learners In The Online Classroom. The Quarterly Review of Distance Education, Volume 8(3), 2007: pp. 233-249

Pandia, W. 2005. Filsafat Ilmu: Diktat Kuliah. Jakarta: STTIP press

PP No. 19 Tahun 2005 tentang Standar Proses Pendidikan

Rustaman, N. 2005. Strategi Belajar Mengajar Biologi. Malang: IKIP Malang (UM) Press

Tim FMIPA Unesa, 2007. Sains Dasar. Surabaya: Unesa University Press

Sagala, S. 2003. Konsep dan Makna Pembelajaran. Bandung: Alfabeta

Silberman, M. 1996. Active Learning: 101 Strategies To Teach Any Subject. Massachusettes: Allyn and Bacon

Slavin, R. 2000. Educational Psychology. USA: Allyn and Bacon

Sudirman. 1991. Ilmu Pendidikan. Bandung: Remaja Rosdakarya 
Suharsimi, A. 2006. Prosedur Penelitan Suatu Pendekatan Praktik. Jakarta: Rineka Cipta

Suprapto, F.A. 2009. Upaya Meningkatkan Kecakapan Akademik (Academic Skills) pada Pembelajaran IPA/Fisika Materi Pemisahan Campuran Menggunakan Problem Base Instruction (PBI). Prosiding Seminar Nasional Fisika Penelitian, Pendidikan, dan Penerapan MIPA UNY 2009: 1521

Suprapto, N dan Supardi, Z. A. 2009. Laporan Penelitian: Penerapan Guided Question Pada Model Guided Discovery pada Kegiatan Praktikum
Fisika Sebagai Upaya Meningkatkan Kinerja dan Pemahaman Konsep Mahasiswa pada Perkuliahan Fisika Dasar. Unesa

Susanto, A. 2009. Penemuan Terbimbing dalam Pemahaman Konsep. Prosiding Seminar Nasional Fisika Penelitian, Pendidikan, dan Penerapan MIPA UNY 2009: 111-117

Yudyanto. 2009. Pengembangan Asesmen Kinerja Melaksanakan Praktikum Elektromagnetik di Jurusan Fisika FMIPA UM. Prosiding Seminar Nasional MIPA UNY: 59-70 